\title{
Proceeding
}

Supplementary Issue: Summer Conferences of Sports Science. First International Conference in Iraq on Sport for Peace, 4 April 2019. Baghdad Science Institute, Baghdad, Iraq.

\section{The strategies for designing desirable territory for improving social interactions at the behavioural setting of the children with autism disorders}

\author{
ARMIN ZARTAJ, FARZANEH ASADI MALEKJAHAN , SEYEDEHMAMAK SALAVATIAN \\ Islamic Azad University, Rasht Branch, Rasht, Iran
}

\begin{abstract}
Improving the social interaction of children with autism is one of the significant factors to be considered in the autism children's behavioural territory. The most vital factor in strengthening social interactions in spaces is the existence of a desirable area for these children. The purpose of this study was establishing a place while preserving their territory for promoting the quality of social interactions of children with autism. Thus, the factors affecting the concept of territory in the autism children's behaviour base was analysed. Two autistic centres of Tehran were selected to test the results. The research method was mixed i.e. both quantitative and qualitative methods were examined in this paper. The results suggest that the desirable territory in the autism children's Behavioural setting is as a manifestation of their social interactions and must meet their social needs and pave the way for accessing and providing the services they need. Moreover, it should bring about the conditions, so that social interactions are continuously established among these children. Thus, the study focused on some aspects such as territory, so that while revealing their significance in the autistic children's Behavioural setting, present some solutions for the practical application of such concepts in designs. Keywords: Desirable territory; Social interactions; Autism; Behavioural setting.
\end{abstract}

\section{Cite this article as:}

Zartaj, A., Malekjahan, F.A., \& Salavatian, S. (2019). The strategies for designing desirable territory for improving social interactions at the behavioural setting of the children with autism disorders. Journal of Human Sport and Exercise, 14(5proc), S2349-S2363. doi:https://doi.org/10.14198/jhse.2019.14.Proc5.50

Corresponding author. Islamic Azad University, Rasht Branch, Rasht, Iran.

E-mail: fasadi@iaurasht.ac.ir

Supplementary Issue: Summer Conferences of Sports Science. First International Conference in Iraq on Sport for Peace, 4 April 2019. Baghdad Science Institute, Baghdad, Iraq.

JOURNAL OF HUMAN SPORT \& EXERCISE ISSN 1988-5202

(c) Faculty of Education. University of Alicante

doi:10.14198/jhse.2019.14.Proc5.50 


\section{INTRODUCTION}

Autism is a complex mental developmental disorder that commonly happens in the first three years of an individual's life. It seems that a disorder in the nervous system leading to poor functioning of the brain is effective in this disease. This disorder in autistic patients makes the brain unable to function properly in social behaviours and communication skills. In the studies conducted by Iranian researchers, exactly one out of every 77 children in the world is born with autism, and it appears that this rate is on the rise, and in Iran, out of every 1,000 children, four children suffer from this disease (Azad, 2015). Autistic children and adults suffer from problems in verbal and nonverbal communication, social behaviours, entertaining activities, and playing. Children with autism have difficulty in treating others, when these children grow older, some of them may be more interested in communicating with others and get less distressed. Others have almost a lifestyle close to a healthy and normal lifestyle.

However, other children still have difficulty in linguistic and social skills, and their disease worsens in adolescence and puberty. Autism spectrum disorder is a developmental disorder associated with social problems, so in ordinary people or mentally retarded people any trespass of the social distance can affect their daily social interactions (Asada et al, 2016). Most children with autism are slow in learning science and skills, with some showing signs of low intelligence. Other children with autism have no difficulties in learning, but they have problems in social, verbal and natural connection. The behaviour or reaction of humans to the environment refers to a mutual relationship between human and the environment. We are humans that interact with the environment all the time. In the course of this interaction, we grow different feelings about different spaces. We consider some of the spaces belonging to us, try to control the entrance of the people into them and see some other spaces as public, and do not see ourselves righteous to control those (Pakzad\&Bozorg, 2012). Humans are as much made up of the physical environment that they are of the social environment. According to social psychology, the four concepts of privacy, personal space, territory and congestion are the base of individual and social behaviours of humans in relation to the environment. Territory monitoring behaviour, as one of the social spatial behaviours of humans with social nature, can greatly affect strengthening the cognitive skills of individuals - both individuals with mental disabilities, especially children with autism (the case of this study) - and social interactions. The hierarchy of social territories manifests itself in the city's architecture and architectural elements. In the process of urban and architecture designing, identifying, evaluating and modelling these territories are important in creating a sustainable social environment. Furthermore, as the significance of a desirable territory and common areas for establishing social solidarity is so vivid, studying the aspects of the desired territory in the Behavioural setting of the children with autism disorders and their important role in increasing social responses and communication behaviours can be significant.

\section{AUTISM DISORDERS}

Autism Spectrum Disorder (ASD) is a group of developmental disorder of the nervous system, of the main causes of which are the defect in social interactions, communication, and the existence of repetitive behaviours and limited interests (Liu et al., 2017). Autism is a kind of developmental (social relationship) disorder characterized by abnormal verbal communication behaviours. Autism is a growth disorder that emerges in the first three years of life. By affecting the child's brain, it disrupts the social behaviours and communication skills. Children and adults with autism have troubles in verbal and nonverbal communication, social interactions, and game-related activities. This disorder makes it difficult for them to communicate with others and the outside world. In some cases, self-harming and aggressive behaviours are seen as well. In these people, repetitive movements (touching, jumping, and so on), unusual responses to people, attachment 
to objects or resistance to change are seen, and they may have unusual sensitivities in the five senses (vision, audition, gustation, olfaction, and touch). The core of autism disorder is disorder in communication. Autism is diagnosed with a set of symptoms, not just one. The main characteristic of autism is deficiency in social reactions, communications, restricted attention, and repetitive behaviours. Other characteristics, such as eating disorder, are important but not necessary for diagnosis (Kennedy\& Adolphs, 2014). As the children with autism cannot read social signs, such as the sign of the face (Baron-Cohen et al, 2001), body language, or tone of voice are in danger. In addition to deficiencies in social abilities and repetitive behaviours, children with autism have a delay in motor abilities. Delay in motor abilities is diverse in autistic children, including delayed sitting, crawling, walking, abnormal walking, poor status control, and disability in motor planning (Hatfield et al, 2017). Autism is considered as a spectrum as its manifestations are very diverse and heterogeneous. For example, cognitive and verbal disabilities are very severe in some of these patients, whereas some others have very high intellectual and talent geniuses (Jiujias et al, 2017). In other words, children with autism are non-verbal. At the head of the autism spectrum, the IQ is under 40 , and on the other, are the genius people with high IQ intelligent, although with deficient in social and communicative interactions (Gross, 2017).

\section{ENVIRONMENT AND SOCIAL BEHAVIOR}

Human is always interacting with an environment, of which he is a part and a social behaviour does not occur in a vacuum and requires a context and is formed in the relationship between humans and the environment. Overall, the environment refers to everything existed around that is potentially related to the individual. However, he does not have access to all available information, and only some of this information is absorbed in the selection of perception (Pakzad \& Bozorg, 2012). The behaviour we use in our relationships with others is full of spatial metaphors, and we usually use these behaviours as the language of our communication. In other words, the quality of our use of space to express how we communicate with others is an important determinant of our everyday behaviour. The human lives in the community and inevitably, his behaviours are a part of them in relation to social interactions, or are somehow affected by social factors, so that the behaviour of a person in loneliness is different from the behaviour among others. Social behaviour is any behaviour that involves the interaction of two or more humans. How we use our physical environment to establish social relationships is in the field of reviewing human social behaviour in relation to the physical environment (Pakzad \& Bozorg, 2012). If social psychology is defined as the study of how people interact with each other and the effect of the actual or implied presence of others on people's thoughts, feelings, and behaviours (Fergus, 2000), any current pattern of human behaviour calls for a satisfactory level of individual relation to social interactions. Territory monitoring behaviour is one of the spatial behaviours of human with social nature, which is one of the important concepts in promoting the quality of human communication with his environment.

\section{THE CAPABILITY OF THE ENVIRONMENT AND COMMUNICATION WITH HUMAN PERCEPTION}

Environmental capability refers to the facilities, information and the structure of the environment that can guide perceptual processes, emotional reactions and the spatial behaviour (actions) by creating motivation to meet human needs. It must be explained that perception is the process of obtaining information from the human environment and cognition has to do with the acquisition, organization and storage of knowledge. The connection between perception and cognition is carried out by subjective schemes designed to exploit the capabilities of the environment in the individual (Lang, 2011). 


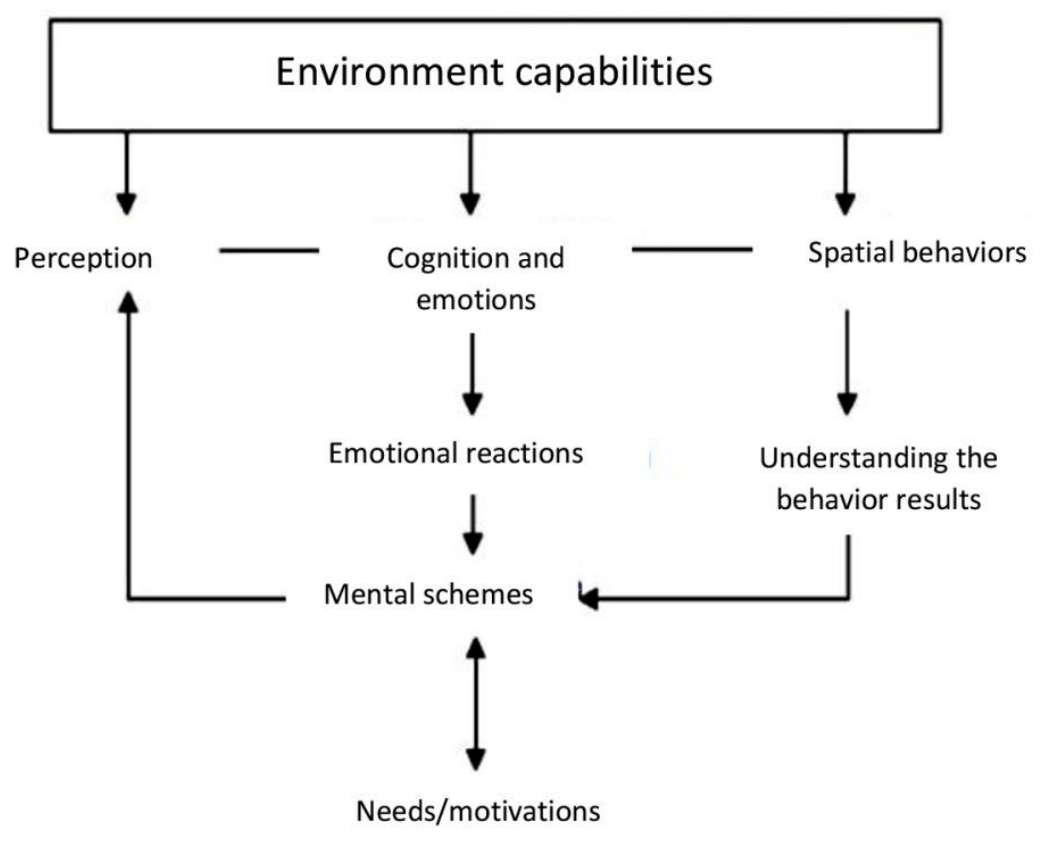

Figure 1. Gibson's Environment Capabilities Model (Lang, 2011).

Given its capabilities, Gibson (1979) considers the environment as a potential source to provide experience and behaviours for human (figure 1). An environment may have specific capabilities for a specific person, but at the same time, these capabilities are meaningless to someone else (mostly due to the lack of knowledge) and that environment does not reveal them to him (Matlabi, 2001). An environment built as fit and in accordance with human needs has the capabilities that "provide" human behaviour. These capabilities may even provide the behaviours of the pets in the environment with the same physical characteristics. Thus, by changing physical levels, an environmental designer, unaware or not willing, may create some capabilities in the environment that provide the opportunities to be discovered by specific (but unpredictable) groups living in that environment (Matlabi, 2001). The environment contains potential features that human beings take in different ways, depending on beliefs and in accordance with their needs, from some or all of these abilities. According to the above, one can consider the environment as a set of all things that surrounds human beings and plays a special role in shaping activities, behaviours and human effects (Asiabi, 2010).

\section{TERRITORY, BEHAVIORAL SETTING, AND TERRITORY MONITORING BEHAVIOR}

Considering language, territory falls within the scope of powers, belongings and possessions. The concept of territory is the area where individuals specifically use it and react to any trespass to it and thereby determine their position in the space. In other words, the territory includes an area of individuals or groups they use and defend as a private sphere. In sum, the main features of spatial territory are 1) the sense of ownership and human right towards a place, 2) the personalization and marking a place, 3) the right to defend against harassment, and 4) the provision of functions from physiological needs to cognitive and aesthetic needs (Lang, 2011). From among the factors affecting the formation of the concept of territory, the following can be cited (Einifar\&Aghalatifi, 2011). 
Table 1. The factors affecting the formation of the concept of territory: (Einifar\&Aghalatifi, 2011).

\begin{tabular}{|l|l|}
\hline $\begin{array}{l}\text { Cognitive - Psychological } \\
\text { factors }\end{array}$ & $\begin{array}{l}\text { The sense of security, the sense of belonging to the space, legibility of the } \\
\text { environment, the needs and motivations of presence in the environment }\end{array}$ \\
\hline Physical factors & $\begin{array}{l}\text { Physical and visual order, equilibrium in open and closed environments, } \\
\text { generalized cluster boundaries, physical boundary structure }\end{array}$ \\
\hline Functional factors & Hierarchy of different functions or hierarchy of accesses, and so on \\
\hline $\begin{array}{l}\text { Geographic-cultural } \\
\text { factors }\end{array}$ & Size, extent and location of the territory, cultural identity, customs and beliefs \\
\hline
\end{tabular}

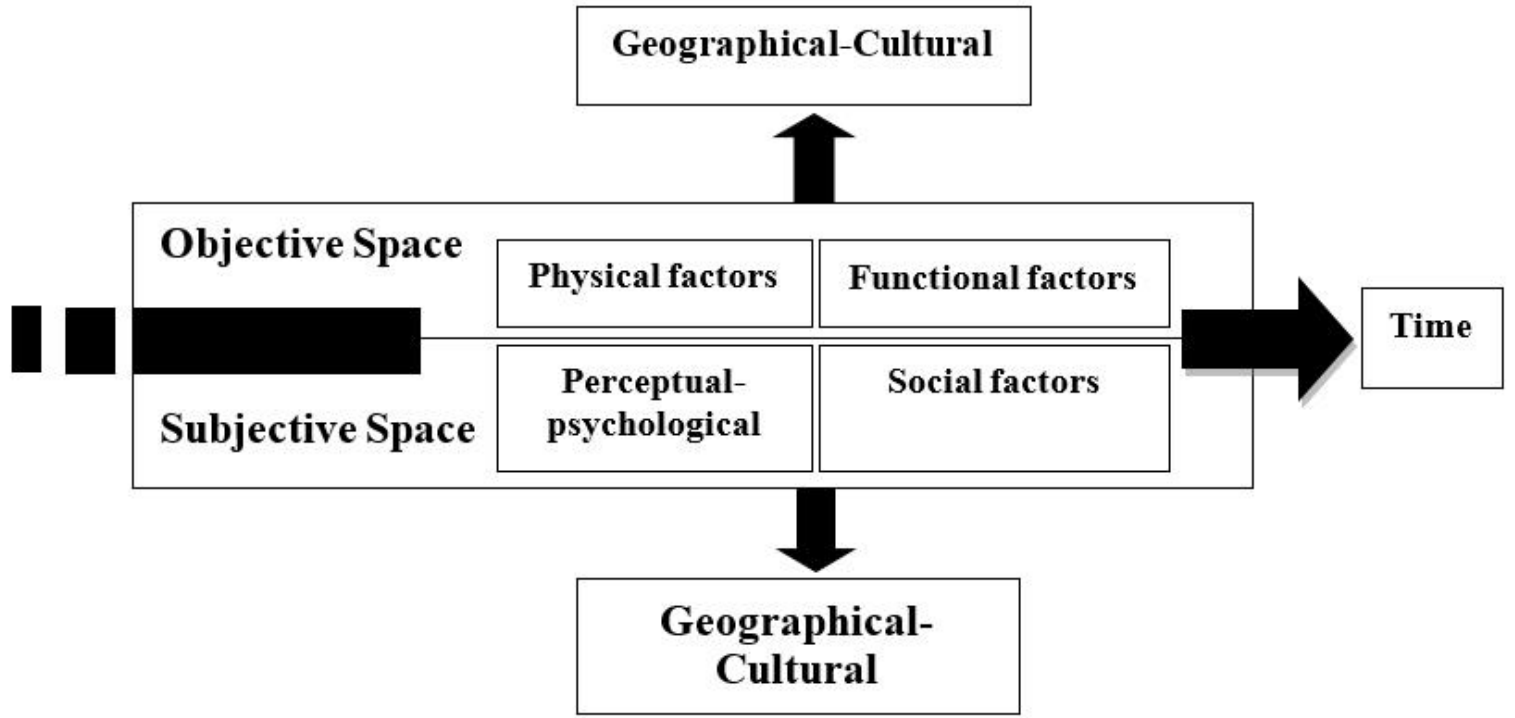

Figure 2. The proposed model of the factors forming territory (Einifar\&Aghalatifi, 2011).

The concept of Behavioural setting in terms of attributes is very similar to that of the territory. According to Barker, a Behavioural setting is a sustainable combination of activity and location, consisting of four main elements:

1- A behavioural pattern always repeated.

2- A platform with its own specific sensation and specificity.

3- Homogeneity, meaning the link between the pattern of behaviour and that context.

4- A specified timespan.

In other words, in this definition, if in a given behavioural context, at different times, different permanent behaviour patterns emerge, that environment is examined as a behavioural and separate entity (Lang, 2011). By matching the characteristics of the territory and the Behavioural setting, we conclude that these two concepts have similarities and differences. The repetitive behavioural pattern of behaviour in the Behavioural setting can be common with the characteristic of meeting the territory needs as any behaviour emerges due to a need. Moreover, homogeneity is similar to the concept of personalization.

However, the means of differentiating these two concepts can be seen in the repetitive pattern of behaviour, sense of belonging, ownership and timing. Indeed, one can conclude that the creation of a territory is the ideal level that environmental designers want to get. The environment where the users have a sense of 
belonging shows the high quality of social interactions in that space. However, if a Behavioural setting has the characteristics of the territory, it is seen as the territory of a Behavioural setting (Ansari et al, 2010).

In order to monitor this specific area (territory), humans and animals show various reactions called territorymonitoring behaviour, which are more complex in humans and vary in terms of time and conditions. Territory monitoring behaviour is one of the mechanisms for monitoring the boundary between itself and another, done by privatizing or marking a place or object, and indicating that the place or object "belongs" to that individual or group (Altman, 2016). According to Lawson, all forms of territory monitoring behaviours have two basic common notions. These two basic and determining notions are first, the territory is vital not only for the sake of physical comfort, but also for social welfare for the survival of a particular species, and secondly, the territory is obtained by provision, organization, and structuring space (Lawson, 2012). In other words, the use of privatization and ownership is in monitoring social interaction that helps meet the physical and social needs. In the event of a trespass to the boundaries of the territory, sometimes defensive reactions are shown (Altman, 2016). Creating a balance between privacy and social interaction is possible through both physical and social-cultural concepts that create the necessary psychological contexts (Einifar, 2000). Thus, territory monitoring is considered as one of the mechanisms of reaching desirable privacy, which can lead to more control of social interactions in the environment by helping organize the artistic environment by creating explicit objective definitions on the delineation and use of space. Thus, strengthening environmental capabilities by considering the social nature of human territory monitoring can help improve the quality of the standard of living and satisfy factors such as maintaining security, enjoying more and better facilities, reducing costs, and enjoying the pleasure of the collective life.

Territory monitoring behaviour is in a huge range of environmental and personal characteristics, and its role in the base of children with autism is undeniable. Territory monitoring behaviour reduces the tensions of the lives of individuals, especially children with autism suffering from nervous stress, and what belongs to whom is an important feature of the outcome of this behaviour. Thus, attention to standards and norms related to territory monitoring behaviour in the Behavioural setting of autism children should first be identified and then prioritized according to the circumstances. Therefore, by organizing the built environment through the creation of explicit objective and subjective definitions, the delineation and use of space in the autism of children's behavioural sphere helps strengthen social skills in the environment.

\section{PROCESS OF THE STUDY}

In this study, to achieve a solution to increase the adaptation of the objective and subjective territories, and then achieve higher levels of desirable territory in the environment of children with autism disorders to enhance their social interactions, first through library studies and reviewing the various views of the experts regarding territory monitoring, a questionnaire with 41 items was developed. Furthermore, a survey of psychiatrists in the field of autistic children in Tehran, parents of autistic children in Tehran and the instructors working in autism centres in Tehran (instructors of Autism centres in Iran) was conducted to reach a structure that can introduce dimensions, criteria and the main principles of territory monitoring behaviour, the main components of this behaviour and the design strategies of the desired territory according to their nature and priority in the two groups of subjective and objective nature in the Behavioural setting of autism children. The research used face and content validity for measuring the validity and variability of data collection tools, which was the questionnaire. Cronbach's alpha coefficient was used to evaluate the reliability of the questionnaire. The designed questionnaire with 41 items had a Cronbach's alpha of $79.2 \%$, indicating a high degree of confidence of the type of questions and measurement scale in relation to the research subject. 
Table 2. The reliability of the items in the questionnaire (Source: the author).

\begin{tabular}{|l|l|}
\hline Reliability Statistics & N of Items \\
\hline Cronbach's Alpha & 41 \\
\hline 79.2 &
\end{tabular}

In the next step, the indices in each item were first identified to analyse the results (using SPSS software) and the data collected were analysed by t-test. The t-test is actually a comparison between the means. When our goal is to examine and compare a mean with a certain value, test value, One-Sample Test is used. This test is based on the assumption that whether a specific sample with a specific mean belongs to the population or not. As at the time of developing the questionnaire, it was assumed that all the items have an effect on the selection of the desired territory, we selected the consent as the test value (Very agree $=5$, agree $=4$, no idea $=3$, disagree $=2$, and Very disagree $=1$ ). The negative numbers in the table below show that item has a mean less than our selected mean $(4=$ agree $)$, which means that the respondents have no idea or disagree. As the number becomes larger, it shows the ineffectiveness of that item in the selection of the territory. Positive numbers show a mean higher than that of our selective mean (4), which means more agreement in that item, and in fact showing the positive effect of it. The cells with limits between positive and negative show that our distribution is normal, meaning that the responses of the respondents have the same dispersion from full agreement to full disagreement. Using t-test, we calculated the mean separately for the respondents, whose results are summarized in the following tables. In terms of the instructors, culture, privacy and social interaction, artificial supervision, social security and solidarity, as well as positioning had no effect on the selection of the desired territory. This is because the mean obtained from these indices was less than our (4) that is evident from the column tand the difference in means, and the severity of this ineffectiveness can also be deduced from the confidence column of $99 \%$. As the negative number is higher, it will be smaller than our selective mean. Indices such as orientation, fitness of climatic conditions, visual permeability, texture and decorations, and so on have had a positive and significant effect on the choice of territory according to the instructors.

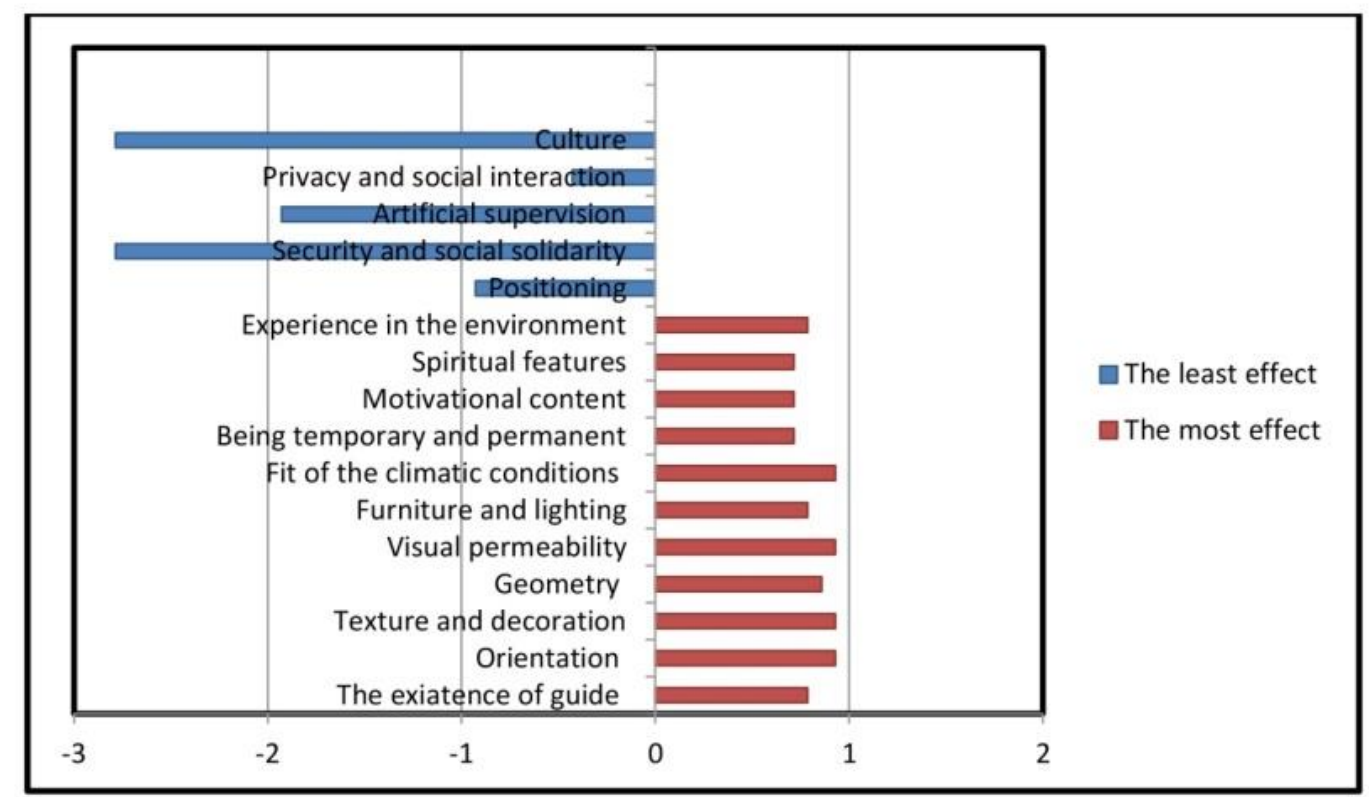

Figure 3. Effective and ineffective factors according to the instructors working in autism centres in Tehran (Source: Writer). 
Table 3. One-sample t-test regarding the views of the instructors working in autism centres in Tehran (Source: the author).

\begin{tabular}{|c|c|c|c|c|c|c|c|}
\hline \multirow{3}{*}{ Instructors } & \multirow{3}{*}{ Items } & \multicolumn{6}{|c|}{ Test Value $=4$} \\
\hline & & \multirow{2}{*}{ T statistic } & \multirow{2}{*}{ Df } & \multirow{2}{*}{ Sig. } & \multirow{2}{*}{$\begin{array}{l}\text { Mean } \\
\text { Difference }\end{array}$} & \multicolumn{2}{|c|}{ With $99 \%$ level of confidence } \\
\hline & & & & & & Min. & Max. \\
\hline \multirow{5}{*}{$\begin{array}{l}\text { The leas } \\
\text { effect }\end{array}$} & Culture & -24.478 & 13 & 0.000 & -2.78571 & -3.1285 & -2.4429 \\
\hline & $\begin{array}{l}\text { Privacy and } \\
\text { social } \\
\text { interaction }\end{array}$ & -3.122 & 13 & 0.008 & -0.42857 & -0.8420 & -0.0151 \\
\hline & $\begin{array}{l}\text { Artificial } \\
\text { supervision }\end{array}$ & -8.707 & 13 & 0.000 & -1.92857 & -2.5958 & -1.2614 \\
\hline & $\begin{array}{l}\text { Security and } \\
\text { social solidarity }\end{array}$ & -13.000 & 13 & 0.000 & -2.78571 & -3.4312 & -2.1402 \\
\hline & Positioning & -4.192 & 13 & 0.001 & -0.92857 & -1.5958 & -0.2614 \\
\hline \multirow{11}{*}{$\begin{array}{l}\text { The mos } \\
\text { effect }\end{array}$} & $\begin{array}{l}\text { Experience in } \\
\text { the } \\
\text { environment }\end{array}$ & 6.904 & 13 & 0.000 & 0.78571 & 0.4429 & 1.1285 \\
\hline & $\begin{array}{l}\text { Spiritual } \\
\text { features }\end{array}$ & 5.701 & 13 & 0.000 & 0.71429 & 0.3369 & 1.0917 \\
\hline & $\begin{array}{l}\text { Motivational } \\
\text { content }\end{array}$ & 5.701 & 13 & 0.000 & 0.71429 & 0.3369 & 1.0917 \\
\hline & $\begin{array}{l}\text { Being } \\
\text { temporary and } \\
\text { permanent }\end{array}$ & 5.701 & 13 & 0.000 & 0.71429 & 0.3369 & 1.0917 \\
\hline & $\begin{array}{l}\text { Fit of the } \\
\text { climatic } \\
\text { conditions }\end{array}$ & 13.000 & 13 & 0.000 & 0.92857 & 0.7134 & 1.1437 \\
\hline & $\begin{array}{l}\text { Furniture and } \\
\text { lighting }\end{array}$ & 3.667 & 13 & 0.003 & 0.78571 & 0.1402 & 1.4312 \\
\hline & $\begin{array}{l}\text { Visual } \\
\text { permeability }\end{array}$ & 13.000 & 13 & 0.000 & 0.92857 & 0.7134 & 1.1437 \\
\hline & Geometry & 8.832 & 13 & 0.000 & 0.85714 & 0.5648 & 1.1495 \\
\hline & $\begin{array}{l}\text { Texture and } \\
\text { decoration }\end{array}$ & 13.000 & 13 & 0.000 & 0.92857 & 0.7134 & 1.1437 \\
\hline & Orientation & 13.000 & 13 & 0.000 & 0.92857 & 0.7134 & 1.1437 \\
\hline & $\begin{array}{l}\text { The existence } \\
\text { of a guide }\end{array}$ & 3.667 & 13 & 0.003 & 0.78571 & 0.1402 & 1.4312 \\
\hline
\end{tabular}


Table 4. One-sample t-test for parents' ideas regarding autistic children in Tehran (Source: The author).

\begin{tabular}{|c|c|c|c|c|c|c|c|}
\hline \multirow{2}{*}{ Parents } & \multirow{2}{*}{ Items } & \multirow{2}{*}{ T } & \multirow{2}{*}{ Df } & \multirow{2}{*}{ Sig. } & \multirow{2}{*}{$\begin{array}{l}\text { Mean } \\
\text { Difference }\end{array}$} & \multicolumn{2}{|c|}{ With $99 \%$ level of confidence } \\
\hline & & & & & & Min. & Max. \\
\hline \multirow{6}{*}{$\begin{array}{l}\text { The least } \\
\text { effect }\end{array}$} & Culture & -17.882 & 43 & 0.000 & -2.11364 & -2.4322 & -1.7951 \\
\hline & $\begin{array}{l}\text { Sense of self- } \\
\text { confidence }\end{array}$ & -3.994 & 43 & 0.000 & -0.72727 & -1.2180 & -0.2365 \\
\hline & $\begin{array}{l}\text { Security and } \\
\text { solidarity }\end{array}$ & -19.102 & 43 & 0.000 & -2.25000 & -2.5675 & -1.9325 \\
\hline & $\begin{array}{l}\text { Need } \\
\text { formation } \\
\text { level } \\
\end{array}$ & -4.469 & 43 & 0.000 & -0.88636 & -1.4209 & -0.3518 \\
\hline & Positioning & -3.172 & 43 & 0.000 & -0.50000 & -0.9248 & -0.0752 \\
\hline & $\begin{array}{l}\text { Territory } \\
\text { dimensions }\end{array}$ & -5.948 & 43 & 0.000 & -1.09091 & -1.5852 & -0.5966 \\
\hline \multirow{5}{*}{$\begin{array}{l}\text { The most } \\
\text { effect }\end{array}$} & $\begin{array}{l}\text { Texture and } \\
\text { decorating }\end{array}$ & 43.000 & 43 & 0.000 & 0.97727 & 0.9160 & 1.0385 \\
\hline & $\begin{array}{l}\text { The } \\
\text { existence of } \\
\text { guidance }\end{array}$ & 14.018 & 43 & 0.000 & 0.86364 & 0.6976 & 1.0297 \\
\hline & $\begin{array}{l}\text { The } \\
\text { existence of } \\
\text { a sign }\end{array}$ & 13.277 & 43 & 0.000 & 0.88636 & 0.7064 & 1.0663 \\
\hline & $\begin{array}{l}\text { Reduction in } \\
\text { noise } \\
\text { pollution }\end{array}$ & 43.000 & 43 & 0.000 & 0.97727 & 0.9160 & 1.0385 \\
\hline & $\begin{array}{l}\text { Physical } \\
\text { differentiation }\end{array}$ & 14.018 & 43 & 0.000 & 0.86364 & 0.6976 & 1.0297 \\
\hline
\end{tabular}

According to the parents, indices such as culture, sense of self-confidence, security and solidarity, the level of need formation, positioning and dimensions of the territory of the choice of the appropriate territory have been ineffective. Indices such as context and decorations, the existence of guidance, the presence of guidance, the reduction of noise pollution and physical differentiation with a mean more than the average defined by the researcher in this study has had the maximum effect on the selection of appropriate territory by autistic children. 


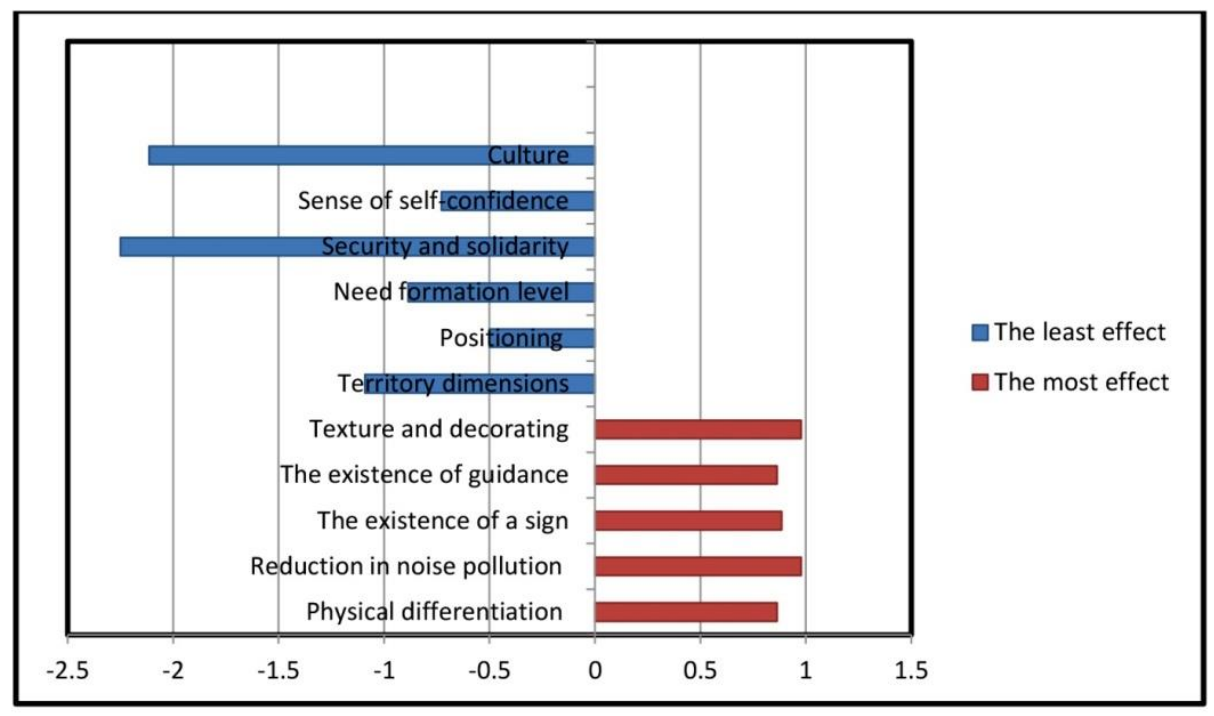

Figure 4. Effective and ineffective factors according to the parent with autistic children in Tehran (Source: The author).

Table 5. One-sample t-test according to the views of psychiatrist regarding the autistic children in Tehran (Source: The author)

\begin{tabular}{|c|c|c|c|c|c|c|c|}
\hline \multirow{2}{*}{ Experts } & \multirow{2}{*}{ Items } & \multirow{2}{*}{ T statistic } & \multirow{2}{*}{ Df } & \multirow{2}{*}{ Sig. } & \multirow{2}{*}{$\begin{array}{l}\text { Mean } \\
\text { Difference }\end{array}$} & \multicolumn{2}{|c|}{ With $99 \%$ level of confidence } \\
\hline & & & & & & Min. & Max. \\
\hline \multirow{4}{*}{$\begin{array}{l}\text { The least } \\
\text { effect }\end{array}$} & Culture & -21.731 & 34 & 0.000 & -2.37143 & -2.6692 & -2.0737 \\
\hline & $\begin{array}{l}\text { Territory } \\
\text { dimensions }\end{array}$ & -5.413 & 34 & 0.000 & -1.02857 & -1.5470 & -0.5101 \\
\hline & $\begin{array}{l}\text { Artificial } \\
\text { supervision }\end{array}$ & -8.474 & 34 & 0.000 & -1.34286 & -1.7752 & -0.9105 \\
\hline & \begin{tabular}{ll|}
$\begin{array}{l}\text { Security } \\
\text { solidarity }\end{array}$ & and
\end{tabular} & -13.994 & 34 & 0.000 & -2.37143 & -2.8338 & -1.9091 \\
\hline \multirow{8}{*}{$\begin{array}{l}\text { The most } \\
\text { effect }\end{array}$} & $\begin{array}{l}\text { Fit with climatic } \\
\text { conditions }\end{array}$ & 12.978 & 34 & 0.000 & 0.88571 & 0.6995 & 1.0719 \\
\hline & $\begin{array}{l}\text { Communication } \\
\text { with peers }\end{array}$ & 9.543 & 34 & 0.000 & 0.82857 & 0.5917 & 1.0655 \\
\hline & $\begin{array}{l}\begin{array}{l}\text { Furniture and } \\
\text { lighting }\end{array} \\
\end{array}$ & 34.000 & 34 & 0.000 & 0.97143 & 0.8935 & 1.0494 \\
\hline & Ease of access & 10.011 & 34 & 0.000 & 0.80000 & 0.5820 & 1.0180 \\
\hline & Orientation & 23.685 & 34 & 0.000 & 0.94286 & 0.8342 & 1.0515 \\
\hline & $\begin{array}{l}\text { The existence } \\
\text { of a sign }\end{array}$ & 23.685 & 34 & 0.000 & 0.94286 & 0.8342 & 1.0515 \\
\hline & $\begin{array}{l}\text { Reduced noise } \\
\text { pollution }\end{array}$ & 34.000 & 34 & 0.000 & 0.97143 & 0.8935 & 1.0494 \\
\hline & $\begin{array}{l}\text { Reduced } \\
\text { congestion }\end{array}$ & 10.011 & 34 & 0.000 & 0.80000 & 0.5820 & 1.0180 \\
\hline
\end{tabular}




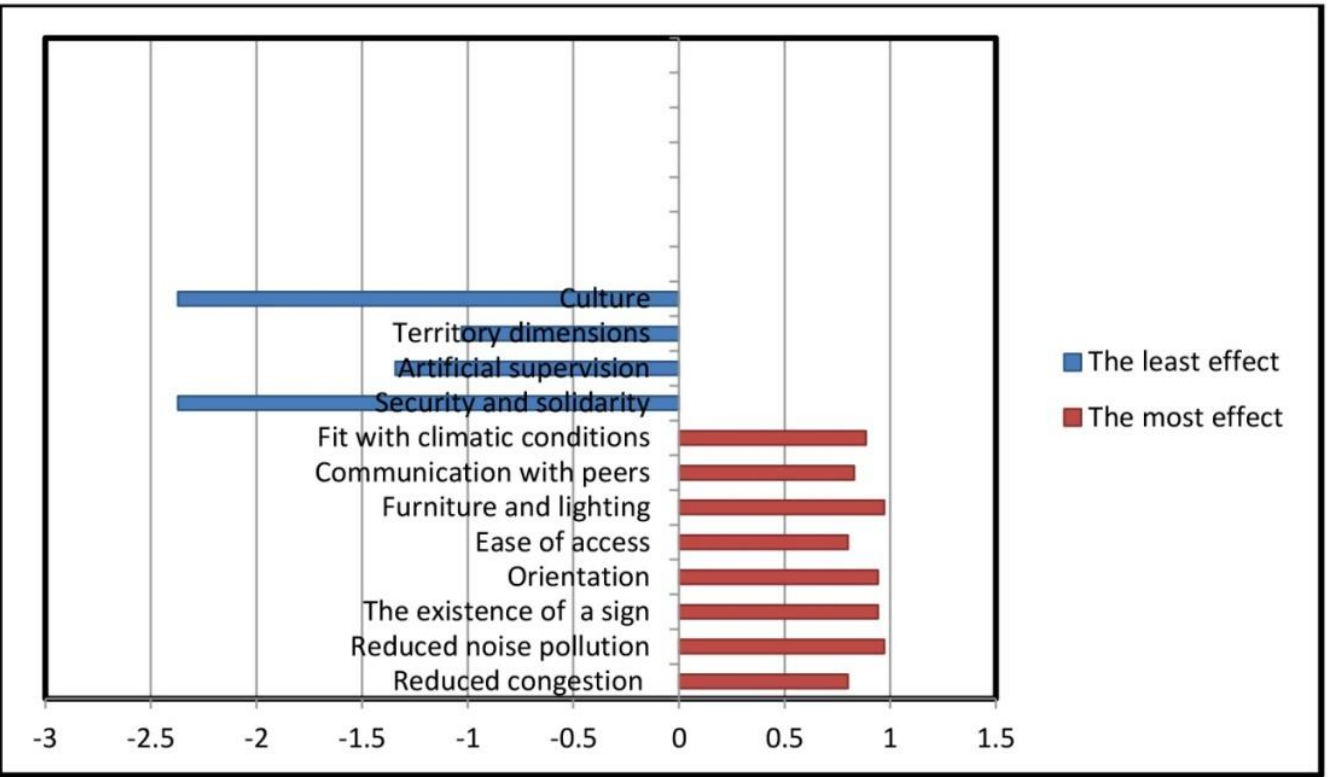

Figure 5. Effective and ineffective factors according to the psychiatrist regarding autistic children in Tehran (Source: The author).

Specialists and physicians have identified indices such as culture, territory dimensions, artificial supervision, and security and solidarity as indifferent indicators and the indices such as climatic conditions, communication with peers, furniture and lighting conditions, ease of access, navigation, noise reduction and congestion reduction considered as more important and more effective. In the next step, with t-test analysis of the three groups (psychiatric specialists in the field of autism in Tehran, parents with autistic children in Tehran and instructors working in autism centres in Tehran), we mention 17 indices with the highest effect in designing the desired territory of children with autism and place them in two groups of the subjective and objective nature of the territory of behaviour.

Table 6. Indices of effective in designing the desirable territory for autistic children (Source: The author).

\begin{tabular}{|l|l|l|l|l|l|l|}
\hline $\begin{array}{l}\text { Subjective } \\
\text { nature }\end{array}$ & $\begin{array}{l}\text { Experience in } \\
\text { the } \\
\text { environment }\end{array}$ & $\begin{array}{l}\text { Congestion } \\
\text { reduction }\end{array}$ & $\begin{array}{l}\text { Spiritual } \\
\text { features }\end{array}$ & $\begin{array}{l}\text { Motivational } \\
\text { contents }\end{array}$ & $\begin{array}{l}\text { Being } \\
\text { temporary } \\
\text { and } \\
\text { permanent }\end{array}$ & $\begin{array}{l}\text { Communication } \\
\text { with peers }\end{array}$ \\
\hline \multirow{2}{*}{$\begin{array}{l}\text { Objective } \\
\text { nature }\end{array}$} & $\begin{array}{l}\text { Fit of the } \\
\text { climatic } \\
\text { conditions }\end{array}$ & $\begin{array}{l}\text { Reduction } \\
\text { in noise } \\
\text { pollution }\end{array}$ & $\begin{array}{l}\text { Furniture } \\
\text { and } \\
\text { lighting }\end{array}$ & $\begin{array}{l}\text { Visual } \\
\text { permeability }\end{array}$ & Geometry & $\begin{array}{l}\text { Texture and } \\
\text { decoration }\end{array}$ \\
\cline { 2 - 6 } & Navigation & $\begin{array}{l}\text { The } \\
\text { existence } \\
\text { of guide }\end{array}$ & $\begin{array}{l}\text { The } \\
\text { existence } \\
\text { of a sign }\end{array}$ & $\begin{array}{l}\text { Physical } \\
\text { differentiation }\end{array}$ & Ease of access \\
\hline
\end{tabular}

In the next step, according to the obtained indices, by dividing each index into two groups, the subjective and objective nature, we present the strategy of designing each of the autism children's behavioural sites. 
Table 7. Subjective strategies in designing the ideal territory for children with autism (Source: The author).

\begin{tabular}{|c|c|c|}
\hline Nature & Index & Designing strategy \\
\hline \multirow{6}{*}{ Subjective } & $\begin{array}{l}\text { Experience in the } \\
\text { environment }\end{array}$ & $\begin{array}{l}\text { Creating memories in the environment using the visual features of } \\
\text { the environment, using parameters that will cause the use of five } \\
\text { senses like sounds, material texture, attention to perspectives to } \\
\text { create a memorable environment that leads to evaluation. The } \\
\text { positive effects of autism children on their territory. }\end{array}$ \\
\hline & Reducing congestion & $\begin{array}{l}\text { Avoid being in overcrowded and congested places not to cause } \\
\text { stress in the nervous system in children with autism }\end{array}$ \\
\hline & Spiritual Features & $\begin{array}{l}\text { The mental characteristics of each child with autism are different. } \\
\text { Considering the individual's mental characteristics in children with } \\
\text { autism causes the positive and negative points of their mental } \\
\text { structure to be identified and used to create a desirable } \\
\text { environment. }\end{array}$ \\
\hline & Motivational content & $\begin{array}{l}\text { Increasing the capabilities of the artistic environment by providing a } \\
\text { platform for diverse activities so that children with autism can } \\
\text { interact with the environment of the territory, depending on their } \\
\text { needs }\end{array}$ \\
\hline & $\begin{array}{l}\text { Being temporary and } \\
\text { permanent }\end{array}$ & $\begin{array}{l}\text { Creating spaces for children with autism to encourage them to use } \\
\text { that space, continuously. }\end{array}$ \\
\hline & $\begin{array}{l}\text { Communication with } \\
\text { peers }\end{array}$ & $\begin{array}{l}\text { Designing social-friendly places for children with autism to address } \\
\text { social activities in this area and enhance their communication skills. }\end{array}$ \\
\hline
\end{tabular}

Table 8. Objective strategies for designing the desirable territory for autistic children (Source: The author).

\begin{tabular}{|l|l|l|}
\hline Nature & Index & Designing strategy \\
\hline \multirow{7}{*}{$\begin{array}{l}\text { Fit of the } \\
\text { climatic } \\
\text { conditions }\end{array}$} & $\begin{array}{l}\text { Attention to the climatic features of the place to design areas of the territory } \\
\text { suitable for the fit climatic conditions, such as shading, and temperature } \\
\text { adjustment and windows face each other for ventilation at high places so } \\
\text { that the children do not tend to escape. }\end{array}$ \\
\cline { 2 - 4 } & $\begin{array}{l}\text { Reducing the } \\
\text { noise } \\
\text { pollution }\end{array}$ & $\begin{array}{l}\text { Attention to the acoustic of the walls in areas of the environment so that it } \\
\text { does not disturb the comfort of people in other areas of the territory }\end{array}$ \\
\hline $\begin{array}{l}\text { Furniture and } \\
\text { lighting }\end{array}$ & $\begin{array}{l}\text { Using moving furniture so that autism children can develop their own } \\
\text { territories if needed and change the layout of their territory in some cases } \\
\text { according to their own taste } \\
\text { In designing lighting, it should be noted that the extreme responses of } \\
\text { children with autism are minimized and prevented from directly observing } \\
\text { the lamp } \\
\text { Balance and coordination with other things, including low vision children } \\
\text { Using the natural light: using sandblasting glass that creates one-handed } \\
\text { light without the dispersion of natural light (Sánchez et al, 2011) } \\
\text { Using artificial light: Light sources less warm in their temperature and colour, } \\
\text { such as inflammatory bulbs (Cherry \& Underwood, 2012) }\end{array}$ \\
\hline $\begin{array}{l}\text { Visual } \\
\text { permeability }\end{array}$ & $\begin{array}{l}\text { Attention to the visual hierarchy in the design of places of the territory so } \\
\text { that children of autism can choose their desired territory according to the } \\
\text { extent of visual permeation within the territory }\end{array}$ \\
\hline
\end{tabular}




\begin{tabular}{|l|l|l|}
\hline Geometry & $\begin{array}{l}\text { Avoiding designing of space with geometry and complex form in such a way } \\
\text { that it does not result in visual disturbances in the territory of the children } \\
\text { with autism. Using curved walls as autistic children like to follow curvature } \\
\text { and find their way around the environment. Avoid using edges and sharp } \\
\text { angles in the walls (Beaver, 2006) }\end{array}$ \\
\hline $\begin{array}{l}\text { Texture and } \\
\text { decorations }\end{array}$ & $\begin{array}{l}\text { Texture and materials should have the slightest detail, shiny materials } \\
\text { reflecting light should be avoided, and fine works should be used for walls } \\
\text { The bright colours with pink and violet colour spectrum should be used, } \\
\text { vegetation and green space should be used }\end{array}$ \\
\hline Navigation & $\begin{array}{l}\text { Easy design for easy access to different areas of the territory and avoid the } \\
\text { complexity of the pathway and mislead the children of autism. }\end{array}$ \\
\hline $\begin{array}{l}\text { The existence } \\
\text { of a guide }\end{array}$ & $\begin{array}{l}\text { Using help elements, such as visual aids, signs and signs for easier access } \\
\text { to the territory where to stand, where to sit, and what to look for (Kabot\& } \\
\text { Reeve, 2010) }\end{array}$ \\
\hline $\begin{array}{l}\text { The existence } \\
\text { of a sign }\end{array}$ & $\begin{array}{l}\text { Using natural elements such as trees and artificial objects, contrasting } \\
\text { colours of spaces, texture, waterfront for recognizing environmental }\end{array}$ \\
\hline \multirow{2}{*}{$\begin{array}{l}\text { Physical } \\
\text { differentiation }\end{array}$} & $\begin{array}{l}\text { The separation of the territory from the surrounding environment by } \\
\text { furniture, flooring, colours plants or fixed and movable walls so that autism } \\
\text { children have a greater sense of independence in their territory than the } \\
\text { surrounding environment and clearly delineate their territory from other } \\
\text { territories. When a child with autism disorder enters a separated space for } \\
\text { a specific pattern of activity, all the cases are foreseen for the child (Mostafa, } \\
\text { 2008) }\end{array}$ \\
\hline $\begin{array}{l}\text { Various designing of the territory areas considering proximity to the main } \\
\text { accesses, entries and proximity to service uses like toilets }\end{array}$ \\
\hline access
\end{tabular}

\section{DISCUSSION AND CONCLUSION}

Considering territory monitoring behaviours in the behavioural setting of the children with autism, as a behaviour with social nature, the present study tried to introduce the main indices of the territory monitoring behaviour in creating a desirable territory. Indices are categorized separately for each index in both groups of subjective and objective nature groups and the designing strategy for each is presented at the behavioural site of autism children. The analysis of important indices in the formation of territory monitoring behaviour of autism children showed that what criteria could be considered from both subjective and objective nature as a desirable area design for these children. What should be cited in this strategy is the high percentage of objective indices relative to mental indices, which is due to the changing mental structure of these children in facing their environment. The structure of the constructed environment should respond to the personal space and the physical requirements of these children as the personalization capability of the environment is affected by its constituent elements. Thus, there is a correlation between the ownership capability of autism children to a place and a feeling of comfort in it and the desire to protect it. Territory monitoring behaviour is considered as one of the mechanisms for reaching a desirable privacy, which can help control the social interactions of autism children in the environment by helping organize the artificial environment and using space. Based on the results of the study and the importance of attention to the different aspects of the behavioural territory of autism children, it can lead to the promotion of communication reactions and increase in the social skills of these children with their environment. 


\section{REFERENCES}

Altman, I. (2016), The environment and social behavior, privacy, personal space, territory and congestion, translation of Ali Namazian, ShahidBeheshti University publications.

Ansari, M., Jamshidi, S., Almasifar, N. (2010), A Survey of Territory and Territory Behavior in Urban Parks, Uranushahr, No. 4, Spring and Summer 2010, pp. 48-33.

Asada , Kosuke. Tojo, Yoshikuni. Osanai , hiroo. Saito , Atsuko. Hasegawa, Toshikazu. Kumagaya, Shinichiro. (2016). Reduced Personal Space in Individuals with Autism Spectrum Disorder. Affiliation Research Center for Advanced Science and Technology, PloS one. https://doi.org/10.1371/journal.pone.0146306

Asiabi, M. (2010) Understanding and expressing the urban environment, Tehran: Tahan / Halleh.

Azad, H. (2015), Pediatric Disease Psychology, Tehran, Payam-e Noor University.

Baron-Cohen, S., Wheelwright, S., Hill, J., Raste, Y., \& Plumb, I. (2001). The "Reading the Mind in the Eyes" test revised version: A study with normal adults, and adults with Asperger Syndrome or highfunctioning autism. Journal of Child Psychology and Psychiatry, 42(2), 241-251. https://doi.org/10.1111/1469-7610.00715

Beaver, C (2006) Designing environments for children and adults with autistic spectrum disorder, Paper presented to International Conference on Autism CapeTown: 22 August.

Cherry CP, Underwood L.(2012). The ideal home for the autistic child physiological rationale for design strategies. Autism Sci Dig J Autismone.

Einifar, A.R. (2000), Human factors - Effective environment in the design of residential complexes, Fine Arts magazine, No. 8, University of Tehran.

Einifar, A.R. Aghlatifi, A. (2011), the concept of territory in residential complexes: a comparative study of two residential complexes in altitude in Tehran, Fine Arts Award, No. 47, pp. 28-17.

Fergus, J.P. (2000). Psychology of Social Interaction: Interpersonal Behavior. Translated by KheshayarBeigi and MehrdadFiruzbakht, Tehran: Abjad.

Gross C. (2017). Defective phosphoinositide metabolism in autism. J Neuro Res; 2017 May.95(5):11611173.

Kennedy, D.P \& Adolphs, R. (2014) Violations of personal space by individuals with autism spectrum disorder.PLoS One. https://doi.org/10.1371/journal.pone.0103369

Jiujias M, Kelley E, Hall L. (2017).Restricted, Repetitive Behaviors in Autism Spectrum Disorder and Obsessive-Compulsive Disorder: A Comparative Review. Child Psych Human Develop:1-16. https://doi.org/10.1007/s10578-017-0717-0

Kabot S, Reeve CE. Setting up classroom spaces that support students with autism spectrum disorders. UTB; 2010.

Lang, J. (2011), Creation of Architectural Theory; The Role of Behavioral Sciences in Environmental Design, translated by AlirezaEinifar, Tehran University Press, Tehran.

Lawson, B. (2012), Space Language, Translated by AlirezaEinfar, FouadKarimian, Tehran University Press, Tehran.

Liu J, Yao L, Zhang W, Xiao Y, Liu L, Gao X, et al.(2017). Gray matter abnormalities in pediatric autism spectrum disorder: a meta-analysis with signed differential mapping. Euro Child Adole Psych:1-1. https://doi.org/10.1007/s00787-017-0964-4

MacDonald M, Hatfield B, Twardzik E. (2017).Child Behaviors of Young Children With Autism Spectrum Disorder Across Play Settings. Adapted Physic ActivQuart.34(1):19-32.

Matlabi, Gh. (2001) New Environmental Knowledge Psychology in the Service of Urban Architecture and Design, Ziba Scientific-Research Quarterly Journal, No. 10, pp. 67-52. 
Mostafa M (2008).An architecture for autism: Concepts of design intervention for the autistic user. International Journal of Architectural Research. 2(1):189-211.

Pakzad, J., Bozorg, H. (2012), Alphabet of Environmental Psychology for Designers, Tehran, ArmanShahr Publications.

Sánchez PA, Vázquez FS, Serrano LA, (2011). Autism and the Built Environment, Autism Spectrum Disorders-From Genes to Environment. InTech Croat. https://doi.org/10.5772/20200 